\title{
PULL AND PUSH FACTORS FOR PRODUCERS' MEMBERSHIP IN DAIRY MARKETING COOPERATIVES IN JIMMA ZONE, OROMIA, ETHIOPIA
}

\author{
Lalisa Fikaduㄹ, Gemeda Duguma², Fikadu Mitiku ${ }^{3 凶}$ \\ ${ }^{\mathrm{l}}$ Wolkite University, Ethiopia \\ ${ }^{2}$ Wollega University, Ethiopia \\ 3Jimma University, Ethiopia
}

\begin{abstract}
Despite the efforts made to promote dairy marketing cooperatives, smallholder dairy producers in rural Ethiopia prefer informal markets to sell their dairy products. The factors determining their preference towards formal markets, such as membership in cooperatives, are not well identified. This paper analyzes the key factors affecting smallholder dairy producers' membership in dairy marketing cooperatives in Ethiopia using cross-sectional survey data from 73 cooperative members and 149 non-members, and probit regression models. The authors found positive effects of age, gender and education of household head and frequency of extension services; and negative effects of distance to the cooperative milk collection centers on the dairy producers' preference for membership in dairy marketing cooperatives. These findings imply the need for awareness initiatives: strengthening extension services, trainings and demonstrations; enhancing access to technology; and infrastructure development. Particularly, affirmative action in the form of targeted intervention is needed to enhance female-headed households' membership in dairy marketing cooperatives and to help them benefit from collective actions.
\end{abstract}

Keywords: dairy marketing cooperatives, producers' participation, membership, Ethiopia

\section{INTRODUCTION}

Agriculture is the basis of the Ethiopian economy and is the most important economic sector in terms of foreign currency generation. The current Ethiopian agricultural policy, which advocates self-sufficiency in food, has led the Ministry of Agriculture (MoA) to spearhead the intensification of activities in support of agricultural development. One concern is the overall improvement and development of the livestock sector. Livestock is a source of income which can be used by the rural population to address their basic needs and purchase agricultural inputs. Its contribution stands second to coffee in foreign exchange earnings (Eshetu, 2015). Livestock's contribution can be equally expressed at household level by its role in enhancing income, food security and social status (Eshetu and Assefa, 2015).

Ethiopia holds a large potential for livestock development in general and dairy development in particular due to its large cattle population, favorable climate, emerging market opportunities, improved policy environment for involvement in private sectors, and the relatively disease-free environment for livestock (Ulfina et al., 2013). However, the absence of clear roadmaps to develop the livestock sector has persistently hindered successful implementation of previous investment plans in Ethiopia (Shapiro et al., 2015). In Ethiopia, dairy

\footnotetext{
$\bowtie$ Fikadu Mitiku, PhD, Department of Agricultural Economics and Agribusiness Management, College of Agriculture and Veterinary Medicine, Jimma University, P.O.Box: 307, Ethiopia, e-mail: fikadom@yahoo.com, ORCID: https://orcid.org/0000-0001-8543-8746
} 
cattle are mainly kept by smallholder farmers who face a wide range of challenges, including high transportation costs, costs of quality services, technology and inputs, costs of meeting standards, and more generally the costs related to coordinating product attributes and delivery conditions. Due to such structural constraints in general and the perishable nature of dairy products in particular, the transaction cost is high among smallholder dairy producers.

The Ethiopian government has stressed the importance of agricultural cooperatives as one of the vehicles to improve commercialization and to alleviate poverty amongst the resource-poor farmers (Getnet and Tsegaye, 2012). These organizations have been targeted as key institutions in national plans to foster rural economic development. Cooperatives play a vital role in adjusting the production of their members to consumer requirements and in improving their market position. According to Yilma et al. (2011), dairy marketing cooperatives play a significant role in ensuring a sustainable supply of raw milk to the dairy industry by coordinating the flow of milk from their members and assisting them by supplying the required dairy farm inputs. According to Bezabih (2009), about 180 cooperatives were engaged in milk production and marketing operation in different parts of the country. However, this number makes only less than one percent of the total number of agricultural and non-agricultural cooperatives. Most dairy cooperatives are based on the principle of profit and productivity maximization through cooperative efforts. This pattern is an integrated cooperative structure that procures, processes, and markets produce (Rajendran and Mohanty, 2004).

Despite the attempts made to organize smallholder farmers into cooperatives and facilitate dairy and dairy products' marketing, Debele and Veschuur (2014) reported that $98 \%$ of milk produced in rural Ethiopia is sold through an informal chain. Most dairy producers have ignored the possibility to participate in formal markets, for instance through cooperative membership. This can be partly attributed to the producers' socio-economic and dairy farms' characteristics (Chagwiza et al., 2016; Tefera et al., 2016).

In the recent past, some efforts have been made to analyze dairy products marketing; dairy products value chains, milk market and competitiveness aspects and common dairy production related problems in different parts of Ethiopia (Bernard et al., 2008; Birhanu, 2012;
Debele and Veschuur, 2014). There are few research results reported on: the constraints cooperative members face in dairy marketing (Bekele and Pillai, 2011); milk supply shortfall (Zekarias and Shiferaw, 2012); and smallholder milk processing and marketing characteristics in the study areas, especially urban dairy farms in the Jimma city (Belay and Janssens, 2014). The later authors have identified the existing patterns of milk production, consumption and marketing, and problems related to milk supply in the same study area.

Bultosa (2016) also studied factors that affect the participation of smallholder dairy farmers in local markets, but did not cover the determinants affecting the participation of smallholder dairy producers in dairy marketing cooperatives. To the knowledge of the researchers, no study on this topic was carried out in the study area. The current study, therefore, bridges this gap by analyzing the key factors affecting smallholder dairy producers' membership in dairy marketing cooperatives in Jimma zone using survey data and econometric models.

\section{EMPIRICAL REVIEW AND CONCEPTUAL FRAMEWORK}

Most smallholder producers in Ethiopia have a chance to join a cooperative. The joining fee that cooperatives charge can be an entry barrier, but cannot be considered as a serious hindrance to cooperative membership. One of the factors that determine the willingness to join a cooperative is likely the farmers' perception of cooperative organizations and other collective actions (Chagwiza et al., 2016).

According to Bernard et al. (2008), Fischer and Qaim (2012) and Nugussie (2010), small-scale and larger-scale producers are less likely to join a cooperative than middle-sized landholder farmers. This is probably due to the high costs incurred by the very small-scale farmers; whereas for large-scale producers, the benefits may not be high enough. Cooperatives play a vital role in technological transformation and knowledge dissemination due to their efficiency in the collective use of technology and existing knowledge. Abate et al. (2014) indicated that agricultural cooperatives enhance productivity and efficiency of Ethiopian farmers at farm level.

Some empirical studies are available, including Eshetu (2015) who shows the roles of cooperatives such as greater economies of scale, market power, risk pooling, coordination of demand and supply and guaranteed 
Fikadu, L., Duguma, G., Mitiku, F. (2019). Pull and push factors for producers' membership in dairy marketing cooperatives in Jimma Zone, Oromia, Ethiopia. J. Agribus. Rural Dev., 1(51), 21-34. http://dx.doi.org/10.17306/J.JARD.2019.01162

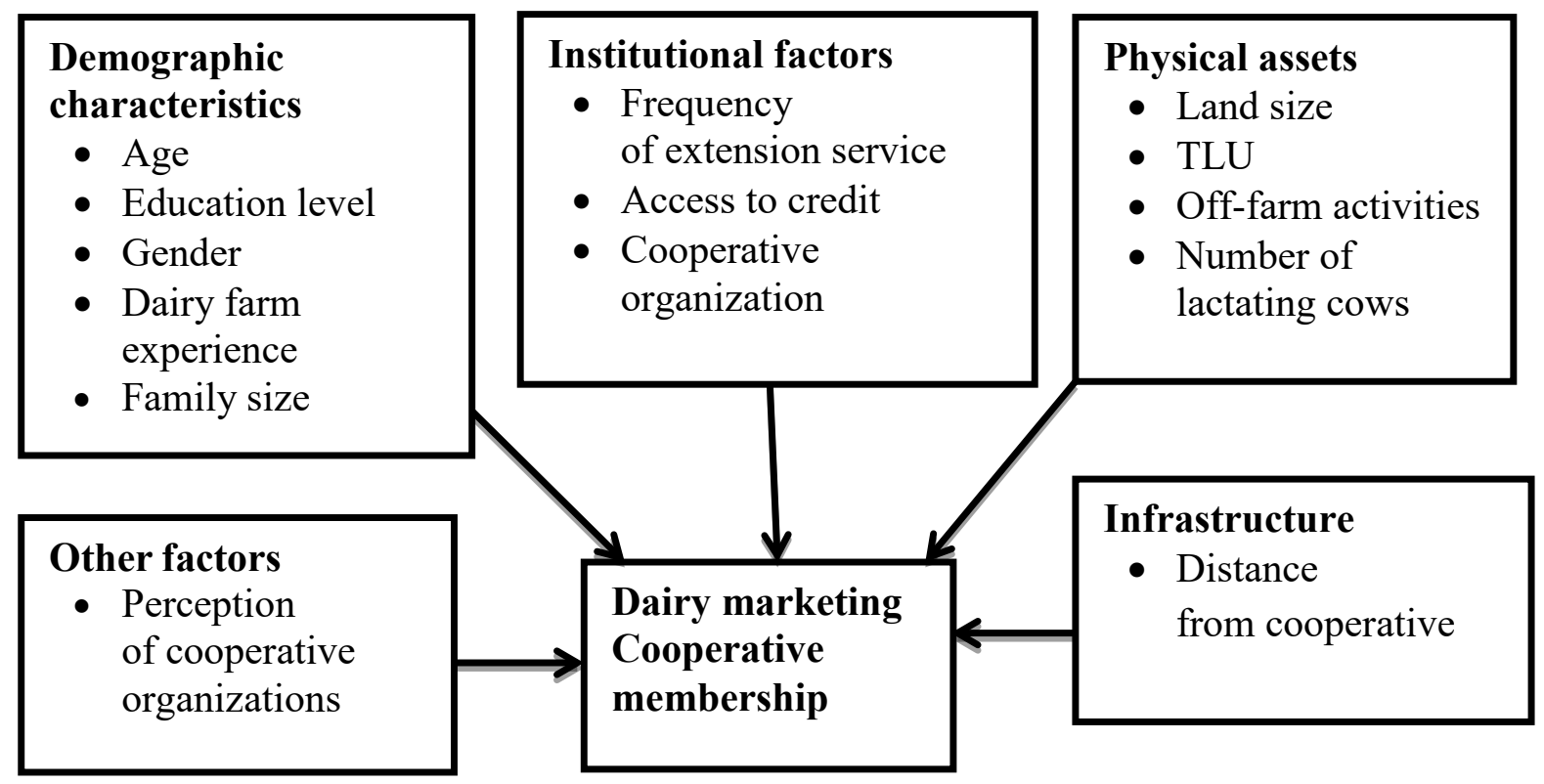

Fig. 1. Conceptual framework for possible factors affecting the dairy producers' membership in dairy marketing cooperatives.

Source: own elaboration based on a literature review.

access to input and output markets to the smallholders; Nugussie (2010) who shows that the likelihood of cooperative membership considerably declines with the distance to a market center in the Sidama zone (Ethiopia); and Chagwiza et al. (2016) who identified that distance to a milk collection center is likely to influence the decision to join a cooperative. Farmers who live far away from the collection center are less likely to become members compared to farmers who live nearby to the cooperative. This illustrates the negative effects of distance on cooperative membership. Chagwiza et al. (2016) also showed the positive influence of family size on the probability of cooperative membership (due to its contribution to labor). Dairy production and product handling are labor-intensive; hence, a large family means the availability of a greater labor force for dairy activities.

Age and education level of the household head are usually used as a proxy for human capital (Fischer and Qaim, 2012). As age and education increase, so does the probability of joining a cooperative (Nugussie, 2010). In addition, land size can play a role in positively influencing the farmers' decision to join a cooperative (Fischer and Qaim, 2012; Karli et al., 2006). Gender of the household head could also be an important determinant of smallholders' membership in cooperatives. Previous studies, such as Nugussie (2010), reveal that male-headed households are more likely to join cooperatives than female-headed. The likely reasons for a smaller number of women joining cooperatives reported by the author was that women are constrained by numerous responsibilities at home more than men. Ma and Abdulai (2016) found that the frequency of extension contact and credit services have positive and significant effects on cooperative membership.

According to Bultosa (2016), the number of lactating dairy cows owned positively and significantly affects the participation of smallholder milk producers in milk marketing. Total livestock holdings, participation in off-farm activities, credit access, and perception of cooperative organizations positively and significantly influence the dairy farmers' participation in dairy marketing cooperatives (Eshetu, 2015). Many explanatory variables that influence the participation of household dairy producers in dairy marketing cooperatives can be postulated with different directions of effects. Figure 1 summarizes the conceptual framework showing possible factors that affect cooperative membership. 


\section{METHODOLOGY}

\section{Description of the study area}

The study was conducted in Southwestern Ethiopia, Oromia region - Jimma city and Kersa district of Jimma Zone. Kersa district and Jimma city are located $325 \mathrm{~km}$ and $346 \mathrm{~km}$ southwest from Addis Ababa, respectively. Both study areas are found adjacent to each other. Some of the kebeles (smallest administrative units) situated at the outskirts of Jimma city that are currently administered by the Jimma city were previously part of the Kersa district. Jimma city has 17 kebeles (13 urban and 4 peri-urban), while the Kersa district has a total of 32 kebeles, including 30 rural and two which are part of the capital town of the district called Serbo. The total population of Jimma city is estimated to be 172,822, of which about 86757 (50.2\%) were males and $86065(49.8 \%)$ were females (Jimma city Agriculture Office, 2016). The total population of the Kersa district is estimated at 178,647 . About 88,252 $(49.4 \%)$ are males and 90,395 (50.6\%) are females (Kersa District Office of Agriculture and Natural Resource, 2016).

The study area is classified into two different agroecologies: midland and highland. About $90 \%$ of the study area falls into midland while the remaining $10 \%$ is highland. The climatic condition of the area is very favorable for agricultural activities in general and for dairy production in particular. The area receives an annual rainfall of about $2000-2400 \mathrm{~mm}$; the mean temperature is $13-26^{\circ} \mathrm{C}$ and the altitude ranges $1750-2200$ $\mathrm{m}$ a.s.l. The distribution of rainfall extends for about eight months of a year, mainly from April to December. Crop production and livestock rearing are the major activities adopted by rural farmers in the area. Rearing of cattle is categorized under the major production activities; the surrounding communities use livestock as income and draught power for farm and non-farm purposes. Dairy is widely produced in the study area. Dairy cattle improvement strategies using Oestrus Synchronization and Mass Artificial Insemination (OISMAI) activities have been undertaken as dairy production upgrading strategies (process upgrading) which in turn improve the dairy breeds and increase the amount of dairy product in the area (KDLFDO, 2016).

\section{Source and type of data}

Both primary and secondary data was used for the study. Primary data was collected from smallholder milk producers and key informant interview. Secondary data was collected from dairy marketing cooperative organizations' documents; Kersa District Livestock and Fishery Development Office (KDLFDO); Jimma Urban Agriculture Office; and Jimma Zone Livestock and Fisheries Development Offices. Relevant published and unpublished reports, bulletins, and websites were also consulted to gather secondary information on dairy marketing cooperatives and dairy value chain. Both qualitative and quantitative data was collected for the study.

\section{Sampling procedure and sample size}

Multi-stage purposive sampling, followed by random sampling strategy, was employed in order to select representative sample respondents. In the first stage, with the consultation of Jimma Zone Livestock and Fishery Development Office, Kersa district and Jimma city administration were purposively selected for the existence of dairy marketing cooperatives. In the second stage, 10 potential kebeles from Kersa district, and Jimma city administration were purposefully identified based on their accessibility and existence of cooperatives. In the third stage, three kebeles from Kersa district were randomly selected. Finally, cooperative members were identified and taken from a cooperative membership list; a list was established of non-cooperative member dairy producers from their respective kebeles in Kersa district and Jimma city urban agriculture. As the number of cooperative members is small (only 73), all of them were included in the study. Non-members were randomly selected from the list of non-cooperative member dairy producers, proportionally to the population size of the selected kebeles (Table 1), at a 93\% confidence interval, following the Yamane (1967:886) formula as specified in equation 1 :

$$
\begin{gathered}
n=\frac{N}{1+N(e)^{2}} \\
n=\frac{560}{1+560(0.07)^{2}}=149
\end{gathered}
$$

Where $n$ is the sample size, $N$ is the non-cooperative member dairy producers' population size, and $e$ is the level of precision (7\%). Finally, a total of 222 sample respondents, 149 non-members and 73 members of diary marketing cooperatives, were surveyed. 
Fikadu, L., Duguma, G., Mitiku, F. (2019). Pull and push factors for producers' membership in dairy marketing cooperatives in Jimma Zone, Oromia, Ethiopia. J. Agribus. Rural Dev., 1(51), 21-34. http://dx.doi.org/10.17306/J.JARD.2019.01162

Table 1. Sample distribution of members and non-members of cooperative dairy producers

\begin{tabular}{|c|c|c|c|c|c|c|}
\hline \multirow{2}{*}{$\begin{array}{l}\text { District } \\
\text { and city }\end{array}$} & \multirow{2}{*}{$\begin{array}{l}\text { Kebele } \\
\text { and city }\end{array}$} & \multicolumn{3}{|c|}{ Non-members } & \multirow{2}{*}{$\frac{\text { Members }}{\text { Sample/population size }}$} & \multirow{2}{*}{ Total sample } \\
\hline & & Population & Proportion & Sample size & & \\
\hline \multirow[t]{3}{*}{ Kersa district } & Marawa & 119 & 0.21 & 32 & 26 & 58 \\
\hline & Babbo & 168 & 0.30 & 45 & - & 45 \\
\hline & Kitimbille & 156 & 0.28 & 41 & - & 41 \\
\hline Jimma city & Jimma city & 117 & 0.21 & 31 & 47 & 78 \\
\hline Total & & 560 & 1 & 149 & 73 & 222 \\
\hline
\end{tabular}

Source: own elaboration based on data from Kersa OLFD and Jimma city Office of Agriculture, 2016.

\section{Data collection method}

A structured questionnaire was developed and administered by experienced and well trained enumerators. The questionnaire was pre-tested before the actual data collection to evaluate its clarity, appropriateness and relevance, and to estimate the time required to fill the questionnaire. Appropriate modifications and corrections were made on the questionnaire based on feedback from the pre-test. Data was collected under close supervision of the researchers. The questionnaire covered different topics in order to capture relevant information related to the study objectives. Though the questionnaire was prepared in English, it was administered in local language, Afan Oromo and Amharic, in order to help respondents clearly speak their minds. In addition to the questionnaire survey, four focus group discussions were held on different topics involving 6-8 participants. Key informant interviews were also conducted at each location with kebele management units, livestock experts and cooperative committees using key informant interview checklists. Suitably, the data generated at various levels was triangulated with field observations and other data sources.

\section{Methods of data analysis}

Descriptive statistics and econometric analysis were used to analyze the data. Frequencies, percentages, means, Chi-square test and $t$-tests were employed to describe the demographic and socio-economic characteristics of households and cooperatives' characteristics.

The probit model was used to estimate the determinants of dairy marketing cooperative membership. The probit model constrains the estimated probabilities to be between 0 and 1, and relaxes the constraint that the effect of independent variables is constant across different predicted values of the dependent variable. In common parlance, the probit model assumes an S-shaped response curve such that in each tail of the curve the dependent variable, $\operatorname{Pr}\left(Y_{i}=1\right)$, responds slowly to changes in the independent variables, while towards the middle of the curve, i.e., towards the point where $\operatorname{Pr}\left(Y_{i}=1\right)$ is closest to 0.5 , the dependent variable responds more swiftly to changes in the independent variables. While only the values of 0 and 1 can be observed for the variable $Y$, the probit model assumes that there is a latent unobserved continuous variable $Y^{*}$ that determines the value of $Y$ (Nagler, 1994). It is assumed that $Y^{*}$ can be specified as follows:

$$
Y^{*}=\beta_{0}+\beta X+u
$$

$$
\text { i.e.: } \begin{aligned}
Y & =1 \text { if } Y^{*}>0 \\
& Y=0 \text { otherwise. }
\end{aligned}
$$

where:

$X$ - represents vectors of explanatory variables defined in Table 2

$\beta_{0}-$ Constant term

$\beta-$ vector of parameters to be estimated

$u-$ a random disturbance term.

The effect of a specific explanatory variable on the probability of cooperative membership is interpreted by means of the marginal effect, which accounts for the partial change in the probability. Based on the empirical review and conceptual framework specified in section 2, the explanatory variables include socio-demographic factors such as age, gender and education (measured in 
Fikadu, L., Duguma, G., Mitiku, F. (2019). Pull and push factors for producers' membership in dairy marketing cooperatives in Jimma Zone, Oromia, Ethiopia. J. Agribus. Rural Dev., 1(51), 21-34. http://dx.doi.org/10.17306/J.JARD.2019.01162

Table 2. Summary of explanatory variables included in the model along with their descriptions and expected signs

\begin{tabular}{|c|c|c|c|c|}
\hline $\begin{array}{l}\text { Explanatory variables } \\
\text { and their description }\end{array}$ & Type & Unit & $\begin{array}{l}\text { Expected } \\
\text { sign }\end{array}$ & Empirical findings \\
\hline Age of household head (AGEHH) & Continuous & Years & + & $\begin{array}{l}\text { Nugussie, 2010; Fischer and Qaim, 2012; } \\
\text { Eshetu, 2015; Chagwiza et al., 2016) }\end{array}$ \\
\hline Gender of household head (GENDER) & Dummy & $\begin{array}{l}1=\text { Male } \\
0=\text { Female }\end{array}$ & + & Nugussie, 2010 and Hadush, 2014 \\
\hline $\begin{array}{l}\text { Education level of the household head } \\
\text { (EDUCLEVEL) }\end{array}$ & Continuous & Years of schooling & + & $\begin{array}{l}\text { Daniel, 2006; Fischer and Qaim, } 2012 \\
\text { and Eshetu, } 2015\end{array}$ \\
\hline Sum total of children $\leq 6$ years (SUMBL6) & Continuous & Number & - & Birhanu, 2012 \\
\hline Family size (adult equiv.) (TOTNFSIZ) & Continuous & Number & $+/-$ & $\begin{array}{l}\text { positively by Chagwiza et al. and nega- } \\
\text { tively Bultosa (2016) }\end{array}$ \\
\hline $\begin{array}{l}\text { Number of livestock in tropical live- } \\
\text { stock units, without lactating dairy cows } \\
\text { (TLULIV) }\end{array}$ & Continuous & Number & + & Eshetu, 2015 \\
\hline $\begin{array}{l}\text { Number of lactating dairy cows } \\
\text { (NLACTCOW) }\end{array}$ & Continuous & Number & + & Meryem, 2013 \\
\hline Area of farmland owned (TLANDSIZ) & Continuous & Hectare & +1 & $\begin{array}{l}\text { Birhanu, } 2012 \text { and Eshetu, 2015, } \\
\text { positively }\end{array}$ \\
\hline $\begin{array}{l}\text { Getting off-farm and non-farm income } \\
\text { (GETOFINCM) }\end{array}$ & Dummy & $1=$ Yes, $0=$ No & $-/+$ & $\begin{array}{l}\text { Bagher, } 2011 \text { negative and Eshetu, } 2015 \\
\text { positive }\end{array}$ \\
\hline $\begin{array}{l}\text { Frequency of extension services accessed } \\
\text { (HOWOFTEN) }\end{array}$ & Continuous & $\begin{array}{l}\text { Number of con- } \\
\text { tacts with devel- } \\
\text { opment agents per } \\
\text { month }\end{array}$ & + & $\begin{array}{l}\text { Hadush, 2014; Ma and Abdulai, } 2016 \\
\text { and Bultosa, } 2016\end{array}$ \\
\hline Access to credit (CREDACES) & Dummy & $1=$ Yes, $0=$ No & + & Eshetu, 2015 \\
\hline $\begin{array}{l}\text { Distance to a cooperative collection center } \\
\text { (DISTANCE) }\end{array}$ & Continuous & Kilometers & - & $\begin{array}{l}\text { Birhanu, 2012; Chagwiza et al., 2016; } \\
\text { Eshetu, } 2015\end{array}$ \\
\hline $\begin{array}{l}\text { Dairy producers' perception of coopera- } \\
\text { tive organizations (COPPERC) }\end{array}$ & Dummy & $\begin{array}{l}0=\text { Not good } \\
1=\text { Good }\end{array}$ & $+/-$ & Eshetu, 2015 \\
\hline
\end{tabular}

Source: own elaboration based on empirical literature, conceptual framework and economic theory.

years of schooling) of the household head; household size excluding children below the age of 6 (measured in adult equivalent); number of children below the age of 6; physical assets such as livestock, excluding lactating cows (measured in tropical livestock units), number of lactating cows, and total land size (measured in hectares); off-farm/non-farm employment (a dummy variable for participation); services such as frequency of extension contact (number of contacts the household had with development agents concerning dairy); access to credit (dummy variable for participation to get any credit from any source); distance of the household from a cooperative milk collection center (measured in kilometers); and the household's perception of membership in a cooperative organization (measured as dummy if the household perceives being a cooperative member as an advantage or not). Details of the definitions, measurements and expected signs of the selected explanatory variables, along with related literature, are summarized in Table 2. 


\section{RESULTS AND DISCUSSION}

\section{Descriptive results}

Household characteristics

Table 3 presents the summary statistics for explanatory variables and compares these among members and non-members of dairy marketing cooperatives. On average, $84 \%$ of the sample households are male-headed. The average age and schooling of household heads are 46 years and 6 years, respectively. The corresponding average age of the cooperative members and non-members was about 49.5 and 44.3 years, respectively. Also, member households are headed by older persons, as compared to non-members, which is consistent with the finding of Chagwiza et al. (2016). Cooperative members are more educated (9.5 years) compared to non-members (3.8 years). This difference can be explained by the fact that most of the cooperative members dwell in the city and have better access to education. The average number of children aged up to 6 years is 1.4, and is lower for members (1.09) than for non-members (1.5). The average family size of the sample households is about 7.24 , with cooperative members having larger families than non-members (7.42 and 7.15, respectively).

On average, sample households own a livestock of 8 units, excluding lactating cows which account for 2.4 units. Members own larger livestock (10.18 units) than non-members (6.92 units). Similarly, the number of lactating dairy cows is significantly higher for cooperative members (3.64 TLU) than for non-members (1.87 units). This is in line with the findings of Eshetu (2015) who reported that members of dairy cooperatives were in a better position with respect to livestock holding, including dairy cows, than non-members. On average, the sample households own 1.6 hectares of land, with non-member households having relatively larger farms (1.72 hectares) than cooperative members (1.35 hectares).

Table 3. Characteristics of sampled households (grouped by cooperative membership status)

\begin{tabular}{|c|c|c|c|c|c|c|c|}
\hline Variables (units) & \multicolumn{2}{|c|}{$\begin{array}{l}\text { Total sample } \\
\qquad(N=210)\end{array}$} & \multicolumn{2}{|c|}{$\begin{array}{l}\text { Members } \\
(N=67)\end{array}$} & \multicolumn{2}{|c|}{$\begin{array}{l}\text { Non-Members } \\
\qquad(N=143)\end{array}$} & $\begin{array}{l}\mathrm{t} \text {-test } / \mathrm{chi}^{2} \\
\left(X^{2} \text { value }\right)\end{array}$ \\
\hline Gender of household head ( 1 if male; \%) & 83.81 & & 64.18 & & 93.06 & & $27.94 * * *$ \\
\hline Age of household head (years) & 45.920 & $(0.796)$ & 49.463 & $(1.261)$ & 44.264 & $(0.981)$ & $-3.102 * * *$ \\
\hline Education level of household head (years) & 5.583 & $(0.310)$ & 9.477 & $(0.486)$ & 3.771 & $(0.285)$ & $-10.716^{* * *}$ \\
\hline Number of children $\leq 6$ years old & 1.355 & $(0.070)$ & 1.089 & $(0.104)$ & 1.479 & $(0.089)$ & $2.619 * *$ \\
\hline $\begin{array}{l}\text { Total family size excluding children }<6 \\
\text { (adult equivalent) }\end{array}$ & 5.88 & $(0.164)$ & 6.33 & $(0.318)$ & 5.664 & $(0.188)$ & $-1.997^{*}$ \\
\hline Total livestock (TLU) & 7.910 & $(0.662)$ & 10.134 & $(0.999)$ & 6.870 & $(0.839)$ & $-2.319 * *$ \\
\hline Total land size (hectare) & 1.599 & $(0.203)$ & 1.346 & $(0.571)$ & 1.718 & $(0.135)$ & 0.854 \\
\hline Number of lactating cows & 2.431 & $(0.176)$ & 3.642 & $(0.381)$ & 1.868 & $(0.169)$ & $-4.942 * * *$ \\
\hline Frequency of extension services & 2.674 & $(0.121)$ & 2.955 & $(0.207)$ & 1.979 & $(0.116)$ & $-4.416 * *$ \\
\hline Off and non-farm participation (\%) & 40.95 & & 31.34 & & 45.45 & & $7.619 * * *$ \\
\hline Credit access $(\%)$ & 15.24 & & 32.84 & & 7.00 & & $23.59 * * *$ \\
\hline Perception of cooperative organizations (\%) & 36.20 & & 52.24 & & 28.67 & & $5.505^{* *}$ \\
\hline Veterinary services $(\%)$ & 58.75 & & 61.24 & & 57.34 & & 0.279 \\
\hline $\begin{array}{l}\text { Distance to a cooperative collection center } \\
(\mathrm{km})\end{array}$ & 7.147 & $(0.393)$ & 2.177 & $(0.365)$ & 9.459 & $(0.430)$ & $10.72 * * *$ \\
\hline
\end{tabular}

$* * * p<0.01 ; * * p<0.05 ; * p<0.10$; standard error in parentheses. The two-sided t-test (chi ${ }^{2}$ test) is computed as the difference in means $(\%)$ between non-members and members.

Source: own elaboration based on survey data. 
The average frequency of extension services provided for sample households by different institutions was 2.7 times per month, with members getting services more often (3 times) than non-members ( 2 times). Forty one percent $(41 \%)$ of sample households participate in off-farm and non-farm activities, with a higher participation rate observed among non-members $(45.45 \%)$ than members $(31.3 \%)$. Only $15 \%$ of sample respondents have access to credit. The reason is that most people in the study area are Muslims; and their religious rules do not permit them to participate in loan/credit access. However, the participation rate is higher among members (32.8\%) than non-members (7\%). About 36\% of sample households perceive cooperatives as good and helpful vehicles in providing services to members. A higher share of members (52.2\%) than non-members (28.7\%) perceive cooperatives to be good. Fifty eight percent $(58.75 \%)$ of the sample respondents used veterinary services for their livestock healthcare. Both sample groups are similar in this regard. They get such services from the government as well as from private service providers. Most private service providers were retired individuals and staff of respective livestock and fishery resources development offices who provide extension services during the weekends. On average, the households are located 7 kilometers away from a cooperative milk collection center. That distance is significantly lower for cooperative members $(2 \mathrm{~km})$ compared to non-members $(9 \mathrm{~km})$.

\section{Cooperative characteristics}

Both cooperatives under the study were primary dairy marketing cooperatives. They provide services such as marketing of milk and milk products in addition to supplying supplementary feed for cows. The cooperative members' report indicated that before joining the dairy cooperatives, milk was often used for household consumption and home-based processing. Most members $(94 \%)$ are supplying raw milk to their cooperative organizations; afterwards, milk quality is tested by cooperatives using a lactometer. The cooperatives receive raw milk for distribution to retailers and consumers, except during fasting seasons where demand for raw milk is low and cooperatives process it to butter and cottage cheese. Cooperative organizations collect milk from members at an average price of ETB 22 (equivalent to 1 US Dollar; a US Dollar was equivalent to ETB 22 during data collection) per liter. They pay a fixed and better price compared to that paid by traders (local collectors and retailers) (ETB 19.85/USD 0.90 per liter, on average), which is flexible and season-dependent.

Cash payment for the supplier cooperative members is on a monthly basis, depending on the volume of milk the person supplied in a month, valued at fixed price per liter. The income obtained from the sale of milk encouraged some of the cooperative members to purchase dairy inputs. For instance, at the end of 2016, members of the Jimma city dairy cooperative organization received a total of ETB 185,488 (USD 8,431.3) as a dividend while the other cooperative has not still made auditing for financial analysis and did not know the dividend. At the time of lower supply of milk by members, the two cooperatives purchase milk from non-members. However, non-members of cooperatives are not entitled to get dividend payments at the end of each audit year, which is in line with the finding of Eshetu (2015). Results of the focus group discussions held with the cooperative committee and of the members' survey revealed that both cooperatives facilitate provision of important dairy related services such as Artificial Insemination (AI), fodder seed and veterinary services provided by government and private organizations. Concentrated feeds were supplied only by the Jimma city cooperative organization. The degree of AI and veterinary services depends on the activities of individual producers.

Moreover, the cooperatives introduced quality milk handling utensils which are made of aluminum cans; plastic utensils, churners, refrigerators, measuring cylinders and milk quality testers like lactometers. A separate focus group discussion held with cooperative members revealed that the cooperatives under investigation did not receive milk supplied by non-members of the cooperatives during the two months of the Orthodox Christian fasting season. Conversely, a high supply of milk (especially from cooperative members) was reported in the wet season.

Furthermore, the discussion with members, committee and cooperative workers revealed that cooperatives have their own fixed milk receiving, processing and distribution houses in Marawa village which belongs to Iftu Marawa and Koci, Bishishe and Hawetu branches of the Jimma city dairy marketing cooperative. They own equipment like mechanical cream separators, electronic milk churners and electrical lactometers. The Jimma city cooperative organization has 8 permanent employees that are working in each of the three branches. But 
the Iftu Marawa cooperative has no permanent employees, i.e. only members are working turn by turn.

The Jimma city cooperative organization has been functioning well ever since it was established. Currently, it is collecting and distributing an average of 586 liters of milk per day to retailers (hotels and restaurants) and consumers. The organization has the necessary equipment used for bulking, storing, processing, quality evaluation and identification of adulteration problems using lactometer measurement. Customers were encouraged to buy raw milk from this organization since the cooperative checks whether or not the milk is mixed with water (adulterated), and because consumers trust the quality milk the cooperative supplies. In contrast, the Iftu Marawa cooperative had started with a full set of dairy processing equipment followed by a good performance in collecting milk from members and non-members. Also, it was able to properly process milk to for different dairy products for more than 3 years. However, since the last two years, the cooperative has been showing weak performance, getting to a point of quitting their business due to a small volume of milk supplied to the cooperative (the maximum and minimum milk collection and distribution volumes were 120 and 35 liters per day, respectively). The reason was that some of the cooperative members were not producers. Instead, they collected milk from nearby producers and supplied it to the cooperative.

Excess milk is processed to butter only during the fasting period as some people do not consume milk during that period. The cooperative organization sells raw milk to the next actors. About six present members of the cooperatives sampled do not supply milk to the cooperative on a daily basis. Sometimes, they process milk using traditional processing methods at home to fill the existing market gap in butter price, while the other $94 \%$ of cooperative member dairy producers supply raw milk to the cooperatives daily.

\section{Cooperative membership criteria}

Every dairy producer/farmer with at least one cow can become a cooperative member. Membership is open for every dairy producer who resides in the area and is able to pay a registration fee and to buy at least one share. The registration fee for the Iftu Marawa dairy marketing cooperative was ETB 40 (USD 1.82). A single share was sold for ETB 50 (USD 2.27) at establishment in 2013. The share value grew over times and currently reached
ETB 100 (USD 4.54). The registration fee for the Jimma city dairy marketing cooperative was ETB 100 (USD 4.54). A single share was sold for ETB 100 (USD 4.54) at establishment in 2006. Currently, the share value is ETB 500 (USD 22.73). The cooperatives have a constitution or bylaw which is a fundamental instrument that defines member duties and responsibilities and the executive committee/board of directors. Cooperative members have to be willing to implement their obligations, obey and respect the objectives and bylaws of the societies.

Both cooperative organizations hold their registered number of members. Iftu Marawa has 40 members of which 18 are female headed while the rest are male-headed households. But from the total members, 14 household heads are non-producers who supply milk to their cooperative by collecting it from nearby producers. The cooperative committee raised as their performance was not good and they needed someone to interfere and encourage them. The Jimma city dairy cooperative organization has 84 members but 37 of them are just shareholders (to earn the member status) rather than producers. The other 47 supply milk daily to the cooperatives at their three different branches. Fifteen of the active members were female-headed households.

\section{Econometric results}

Determinants of membership

in dairy marketing cooperatives

Before running the probit model, the presence of multicollinearity was checked. The VIF values for the continuous variables were found to be small (less than 2), showing that the data is not affected by multicollinearity (Table 4). The contingency coefficient test also showed a low degree of association among dummy independent variables (Table 5).

The probit model results are given in Table 6 and are interpreted accordingly. The probit model estimation gave a Pseudo- $R^{2}$ of 0.64 which implies that the variables included in the model were able to explain about 64 percent of the probability of the farm households' decisions to become member of dairy cooperatives. The chi-square tests for the model also indicate that the overall goodness-of-fit of the probit model was statistically significant at a probability of less than $1 \%$. This shows that the independent variables included in the model jointly significantly explained the probability of dairy producers' participation in dairy marketing 
Fikadu, L., Duguma, G., Mitiku, F. (2019). Pull and push factors for producers' membership in dairy marketing cooperatives in Jimma Zone, Oromia, Ethiopia. J. Agribus. Rural Dev., 1(51), 21-34. http://dx.doi.org/10.17306/J.JARD.2019.01162

Table 4. Multicollinearity test for continuous explanatory variables

\begin{tabular}{lcc}
\hline \multicolumn{1}{c}{ Variables } & VIF & Tolerance $\left(\mathrm{R}^{2}\right)$ \\
\hline Education level (EDUCLEVEL) & 1.89 & 0.529 \\
Total land size owned in hectares (TLANDSIZ) & 1.65 & 0.608 \\
Number of lactating dairy cows (NLACTCOW) & 1.58 & 0.631 \\
Distance from coop collection center in km (DISTANCE) & 1.43 & 0.700 \\
Frequency of extension services (HOWOFTEN) & 1.42 & 0.705 \\
Age of household head in years (AGEHH) & 1.32 & 0.757 \\
Total number of livestock in tropical units (TLULIV) & 1.28 & 0.783 \\
Family size as total number of adult equiv. (TOTNFSIZ) & 1.23 & 0.815 \\
Total number of children aged $\leq 6$ years (SUBMFL6) & 1.22 & 0.819 \\
Mean of VIF & 1.446 & \\
\hline
\end{tabular}

Source: own elaboration based on survey data.

Table 5. Contingency coefficient for discrete independent variables

\begin{tabular}{lcccc}
\hline & SEXHH & CREDACES & GETOFFINOM & COPPERC \\
\hline SEXHH & 1.0000 & & & \\
CREDACES & 0.2459 & & 1.0000 & \\
GETOFFINCOM & -0.0248 & 0.1582 & 1.0000 & \\
COPPERC & -0.0476 & -0.1783 & -0.0769 & 1.0000 \\
\hline
\end{tabular}

Source: own elaboration based on survey data.

cooperatives. Given the abovementioned goodness-offit measures, the probit model employed is concluded to be reliable and appropriate. Also, it is consistent with Dehinenet (2014).

The results show that age, gender and education of household head and frequency of visits by extension agents positively and significantly influence dairy producers' membership in dairy marketing cooperatives. However, the distance from cooperative milk collection centers has negative and significant effects on the probability of membership in dairy marketing cooperatives. The marginal effect estimate for the age of household head is 0.007 , implying that as age increases by one year, the probability of being a cooperative member increases by $0.7 \%$. This is in line with the findings of previous studies (Nugussie, 2010; Fischer and Qaim, 2012; Eshetu, 2015 and Chagwiza et al., 2016).
Gender of the household head is an important determinant of cooperative membership. There is a statistically significant marginal effect estimate of 0.297 implying that being male-headed increases the probability for a household to become member of a cooperative by $29.7 \%$. This finding is in line with the authors' expectation and the findings of Nugussie (2010) and Hadush (2014) indicating that membership of femaleheaded households into cooperatives is by far limited due to cultural impediments and because females are left at home to attend the household chores or perform daily routine tasks more often than males. Furthermore, men are the ones who attend meetings of local organizations, participate in any decision-making activities and other local organizations such as Idir, Ikub and dabo more often than women. Formal education also matters in the decision to become a dairy cooperative 
Fikadu, L., Duguma, G., Mitiku, F. (2019). Pull and push factors for producers' membership in dairy marketing cooperatives in Jimma Zone, Oromia, Ethiopia. J. Agribus. Rural Dev., 1(51), 21-34. http://dx.doi.org/10.17306/J.JARD.2019.01162

Table 6. Results of probit model estimates and marginal effects of the determinants of cooperative membership

\begin{tabular}{|c|c|c|c|c|c|c|}
\hline \multirow{2}{*}{$\begin{array}{c}\text { Variables } \\
\text { Age of household head }\end{array}$} & \multicolumn{2}{|c|}{ Coefficient } & \multicolumn{2}{|c|}{ Marginal effect $(d y / d x)$} & \multirow{2}{*}{$\begin{array}{c}Z \\
1.75\end{array}$} & \multirow{2}{*}{$\begin{array}{l}P>|z| \\
0.079\end{array}$} \\
\hline & $0.029 *$ & $(0.016)$ & 0.007 & $(0.004)$ & & \\
\hline Gender of household head & $1.181 * * *$ & $(0.400)$ & 0.297 & $(0.107)$ & 2.87 & 0.005 \\
\hline Education level & $0.141 * * *$ & $(0.045)$ & 0.035 & $(0.012)$ & 2.92 & 0.003 \\
\hline Sum of children $\leq 6$ years old & -0.107 & $(0.164)$ & -0.027 & $(0.041)$ & -0.66 & 0.511 \\
\hline Total family size (AE) & 0.114 & $(0.071)$ & 0.029 & $(0.018)$ & 1.57 & 0.115 \\
\hline Total livestock & 0.049 & $(0.039)$ & 0.012 & $(0.010)$ & 1.22 & 0.221 \\
\hline Number of lactating cows & 0.037 & $(0.109)$ & 0.009 & $(0.027)$ & 0.34 & 0.736 \\
\hline Total land size & -0.005 & $(0.052)$ & -0.001 & $(0.013)$ & -0.11 & 0.915 \\
\hline Off-farm and non-farm activities & -0.359 & $(0.316)$ & -0.087 & $(0.075)$ & -1.17 & 0.243 \\
\hline Frequency of extension services & $0.252 * *$ & $(0.098)$ & 0.063 & $(0.026)$ & 2.41 & 0.016 \\
\hline Access to credit & -0.143 & $(0.434)$ & -0.034 & $(0.098)$ & -0.35 & 0.727 \\
\hline Distance from cooperative & $-0.129 * * *$ & $(0.037)$ & -0.033 & $(0.008)$ & -3.87 & 0.000 \\
\hline $\begin{array}{l}\text { Perception of membership in a co- } \\
\text { operative organization }\end{array}$ & -0.053 & $(0.315)$ & -0.013 & $(0.079)$ & -0.17 & 0.867 \\
\hline Constant & $-5.197 * * *$ & $(1.234)$ & & & -4.21 & 0.000 \\
\hline
\end{tabular}

Number of observations $=210$

$\operatorname{LR} \operatorname{chi}^{2}(13)=169.26$

Prob $>c h i^{2}=0.0000$

Log pseudo likelihood $=-46.86$

Pseudo $R^{2}=0.6436$

Note: figures in parenthesis are robust standard errors for their respective coefficients and marginal effects.

$* * * P<0.01 ; * * P<0.05 ; * P<0.10$. Marginal effects are regressed for each $y$ of the variable list.

Source: own elaboration based on survey data.

member. The model result confirms that educated dairy producers are more likely to become a member of a dairy marketing cooperative than those who are not educated. The marginal effect of 0.035 implies that when education increases by one year, the probability of membership in dairy marketing cooperatives increases by $3.5 \%$. This result conforms to the authors' expectation and implies that education enhances the farmers' awareness of working in cooperatives, which is consistent with most participation studies (Chagwiza et al., 2016; Eshetu, 2015; Fischer and Qaim, 2012; Nugusse et al., 2013). Educated farmers have more access to information and are more aware to understand the use and benefits of cooperatives, and such awareness enhance their participation in market-oriented activities.
The frequency of extension contact also increases the probability of cooperative membership. The marginal effect is 0.063 , implying that as far as the frequency of extension contact increases on a monthly basis, the probability level of cooperative membership increases by $6.3 \%$. This is in line with the authors' expectation and the findings of Bultosa (2016). Frequent visit of agricultural extension agents and their technical assistance improves the farmers' awareness of benefits from adopting dairy production technologies like dairy breed improvements, AI services, veterinary services, and other dairy inputs (Ma and Abdulai, 2016; Hadush, 2014). A one-kilometer increase in the distance from dairy cooperative milk collection centers decreases the probability of cooperative membership by $8.3 \%$. It implies that the longer the distance between the farmer's residence 
from the cooperative milk collection centers, the lower the probability of dairy cooperative membership. Proximity to market reduces transaction costs. The result is in line with the findings of Birhanu (2012), Eshetu (2016) and Chagwiza et al. (2016).

\section{CONCLUSION AND IMPLICATIONS}

The authors used a unique cross-sectional survey data from dairy marketing cooperative members and nonmembers, and descriptive and econometric models to study the determinants of smallholder dairy producers' cooperative membership. Cooperative members and non-members were found to clearly differ in their socioeconomic and institutional characteristics and in access to infrastructure and services. Cooperative members are in a better position in terms of: household head education, family labor, livestock size, number of lactating cows; access to credit, extension services, veterinary services; and proximity to cooperative milk collection sectors. Though the cooperatives studied are small in size, the study also revealed the importance of the cooperative's internal capacity to serve its members. One of the cooperatives studied is strong in terms of facilities, equipment, and the service it provides for members and dividend payments whereas the other is weak and does not perform well.

The econometric results revealed important determinants of membership in dairy marketing cooperatives. The household head's age, gender, education, and frequency of extension services are among the factors that encourage smallholder dairy producers to become members of dairy cooperatives. Conversely, the distance to dairy marketing cooperative milk collection centers is among the discouraging factors for joining dairy marketing cooperatives. Five of the variables that significantly affect membership are consistent with the authors' expectations and in line with the findings of other studies.

These findings imply that market access through a cooperative is very important for dairy producers as it facilitates the sale of milk in relatively larger quantities while enabling a stronger bargaining power, higher prices and risk pooling; and assists members in procuring the necessary inputs such as concentrate feeds at fair prices. Overall, the findings from this study indicate that cooperatives can be considered a vehicle for milk commercialization. Smallholder dairy producers with limited resources reap substantial benefits from cooperative membership through the effects of intensification in production systems. Therefore, despite structural limitations and functional trade-offs they face, dairy marketing cooperatives can be regarded as suitable business institutions to promote improved livelihoods and dairy producers' economic development in the study area.

There is room for intervention at different levels of governmental and non-governmental organizations to expand and strengthen cooperatives and attract nonmember dairy producers to join cooperatives and benefit from the niche market. This could be enabled through awareness initiatives; strengthening extension and other complementary services; enhancing access to technology; extending trainings and experience sharing with model dairy cooperatives in the country; demonstrations; and infrastructure development to reduce transaction costs. Expanding the capacity of the non-member dairy marketing cooperatives and creating additional access to inputs through integrated dairy investment is important to increase dairy income, and thereby to improve the household's ability to buy other inputs (like concentrated feeds) and improve their welfare. Particularly, affirmative action in the form of targeted intervention is needed to help female-headed households benefit from collective actions. It is probably the mandate of experts of Kersa district and Jimma city cooperative promotion agencies and Fisheries and Livestock development Office to encourage and empower non-cooperative member smallholder dairy producers; to organize and help them in preparing a business plan and train them on the importance and benefits of operating through cooperatives rather than independently searching opportunistic traders for their milk and milk products. The zonal and district administrations have to focus on solving the bottlenecks related to managerial and administrative aspects. They need to identify which problem should be solved by whom and give the necessary administrative supports to circumvent the problems.

\section{SOURCE OF FINANCING}

The authors would like to acknowledge the financial support provided by the LIVES-ILRI for this research.

\section{REFERENCES}

Abate, G. T., Francesconi, G. N., Getnet, K. (2014). Impact of agricultural cooperatives on smallholders'technical 
Fikadu, L., Duguma, G., Mitiku, F. (2019). Pull and push factors for producers' membership in dairy marketing cooperatives in Jimma Zone, Oromia, Ethiopia. J. Agribus. Rural Dev., 1(51), 21-34. http://dx.doi.org/10.17306/J.JARD.2019.01162

efficiency: empirical evidence from Ethiopia. Ann. Public Coop. Econ., 85(2), 257-286.

Belay, D., Janssens, G. P. J. (2014). Smallholder milk processing and marketing characteristics at urban dairy farms in Jimma town of Oromia Regional State, Ethiopia. Global Vet., 13(3), 285-292.

Bekele, A. D., Pillai, G. B. (2011). Training needs of members in cooperative dairy marketing in Ethiopia. Afr. J. Agric. Res., 6(2), 488-507.

Bernard, T., Taffesse, A. S., Gabre, M. E. (2008). Impact of cooperatives on smallholders' commercialization behavior: evidence from Ethiopia. Agric. Econ., 39(2), 147-161.

Bezabih, E. (2009). Cooperatives: a path to economic and social empowerment in Ethiopia. ILO.

Birhanu, K. (2012). Market access and value chain analysis of dairy industry in Ethiopia: The case of Wolaita Zone (Doctoral dissertation, Haramaya University).

Bultosa, T. (2016). Key factors affecting market participation of small. Paper for presentation at the 14 th International Conference on the Ethiopian Economy. Ethiopian Economic Association (EEA) Conference Centre, Addis Ababa, Ethiopia, July 21-23, 2016.

Chagwiza, C., Muradian, R., Ruben, R. (2016). Cooperative membership and dairy performance among smallholders in Ethiopia. Food Policy, 59, 165-173.

Debele, G., Verschuur, M. (2014). Analysis of milk value chain: the case of Ada'a dairy cooperative in Ada'a district, East Shawa zone of Oromia regional state, Ethiopia. J. Agric. Res., 3(1), 16-25.

Dehinenet, G. (2014). Analyses of impact of improved dairy technology adoption on smallholder household livelihoods and milk value chain in selected Zones of Oromia and Amhara National. Doctoral dissertation, College of Veterinary Medicine and Agriculture, Addis Ababa University.

Eshetu, T. (2008). The role of dairy cooperatives in stimulating innovation and market oriented smallholders development: the case of Ada'a dairy cooperative, Central Ethiopia. Doctoral dissertation, Haramaya University.

Eshetu, T. (2015). Performance and determinants of household's participation in dairy marketing cooperatives: The Case of Lemu-Arya and Bekoji Dairy Marketing Cooperatives, Arsi Zone, Oromia Region, Ethiopia.

Eshetu, T., Assefa, G. (2015). Performance and determinants of household's participation in dairy marketing cooperatives: The case of Lemu-Arya and Bekoji dairy marketing cooperatives, Arsi zone, Oromiya region, Ethiopia: Global Sci. Res. J., 3(3), pp. 214-229.

Fischer, E., Qaim, M. (2012). Linking smallholders to markets: determinants and impacts of farmer collective action in Kenya. World Dev.t, 40(6), 1255-1268.
Getnet, K., Tsegaye, A. (2012). Agricultural cooperatives and rural livelihoods: Evidence from Ethiopia. Ann. Public Coop. Econ., 83(2), 181-198.

Girma, D., Verschuur, M. (2014). Analysis of milk value chain: the case of Ada'a dairy cooperative in Ada'a district, East Shawa zone of Oromia regional state, Ethiopia. J. Agric. Res., 3(1), 16-25.

Hadush, H. (2014). Adoption and impact of micro irrigation on household income: The case of Eastern Tigray. Doctoral dissertation, Mekelle University.

Jimma city Agriculture Office (2016). Annual work report.

Jimma Zone Livestock and Fisheries Development Offices (2016). Documentary data.

Karli, B., Bilgiç, A., Çelik, Y. (2006). Factors affecting farmers' decision to enter agricultural cooperatives using random utility model in the South Eastern Anatolian region of Turkey. J. Agric. Rural Dev. Trop. Subt. (JARTS), 107(2), $115-127$.

KDFLDO (Kersa District Livestock and Fishery Development Offices) (2016). Annual Ousterus Synchronization work report.

KDFLDO (Kersa District Livestock and Fishery Development Offices) (2017). Annual work report.

Kersa District Office of Agriculture and Natural Resource (2016/2017). Annual work report.

Ma, W., Abdulai, A. (2016). Does cooperative membership improve household welfare? Evidence from apple farmers in China. Food Policy, 58, 94-102.

Meryem, K. (2013). Analysis of Cow Milk Market Chain: The Case of Sululta District, Oromia Special Zone Surrounding Finfinne, Ethiopia, Master Thesis, Haramaya University.

Nagler, J. (1994). Scobit: an alternative estimator to logit and probit. Am. J. Polit. Sci., 38(1), 230-255.

Nugussie, W. Z. (2010). Why some rural people become members of agricultural cooperatives while others do not. J. Dev. Agric. Econ., 2(4), 138-144.

Nugusse, W. Z., Van Huylenbroeck, G., Buysse, J. (2013). Determinants of rural people to join cooperatives in Northern Ethiopia. Int. J. Soc. Econ., 40(12), 1094-1107.

Rajendran, K., Mohanty, S. (2004). Dairy cooperatives and milk marketing in India: constraints and opportunities. J. Food Dist. Res., 35(2), 34-41.

Shapiro, B. I., Gebru, G., Desta, S., Negassa, A., Nigussie, K., Aboset, G., Mechal, H. (2015). Ethiopia livestock master plan. ILRI Project Report. Nairobi, Kenya: International Livestock Research Institute (ILRI).

Tefera, A. D., Bijman, J., Slingerland, A. M. (2016). Agricultural Co-operatives in Ethiopia: Evolution, Functions and Impact. J. Int. Dev., 29, 431-453. 
Fikadu, L., Duguma, G., Mitiku, F. (2019). Pull and push factors for producers' membership in dairy marketing cooperatives in Jimma Zone, Oromia, Ethiopia. J. Agribus. Rural Dev., 1(51), 21-34. http://dx.doi.org/10.17306/J.JARD.2019.01162

Ulfina, G., Jiregna, D., Alganesh, T., Shiv Prasad, L., Mulugeta, K. (2013). Dairy production potential and challenges in western Oromia milk value chain, Oromia, Ethiopia. J. Agric. Sust., 2(1), 1-12.

Uzunoz, M., Akcay, Y. (2012). A case study of probit model analysis of factors affecting consumption of packed and unpacked milk in Turkey. Econ. Res. Int., 1-8. http:// dx.doi.org/10.1155/2012/732583
Yilma, Z., Emmanuelle, G., Ameha, S., Rudolf, F. (2011). A review of the Ethiopian dairy sector. Addis Ababa, Ethiopia: FAO Sub Regional Office for Eastern Africa (FAO/ SFE).

Zekarias, S., Shifaraw, M. (2012). Milk Supply Shortfall in Jima Town-An Option for Investment. World J. Agric. Sci., 8(4), 366-374. 